\begin{tabular}{|c|c|c|}
\hline & Int.J.Curr.Microbiol.App.Sci (2018) 7(3): 312-322 & \multirow{2}{*}{ 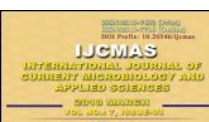 } \\
\hline & \multirow{3}{*}{$\begin{array}{l}\text { International Journal of Current Microbiology and Applied Sciences } \\
\text { ISSN: 2319-7706 Volume } 7 \text { Number } 03 \text { (2018) } \\
\text { Journal homepage: http://www.ijcmas.com }\end{array}$} & \\
\hline & & \\
\hline \begin{tabular}{|l} 
EXCELLENT \\
PUBL ISHERS
\end{tabular} & & \\
\hline
\end{tabular}

\title{
Influence of Conservation Agriculture Practices on Biological Soil Quality
}

\author{
B.T. Naveen Kumar* and H.B. Babalad \\ Department of Agronomy, College of Sericulture, UAS, Karnataka - 563125, India \\ *Corresponding author
}

\begin{abstract}
Keywords
Conservation tillage,

Conventional tillage,

Enzyme activity,

Microbial biomass

carbon, Microbial

biomass nitrogen

Article Info

Accepted:

04 February 2018

Available Online:

10 March 2018 situations. The pooled data reveled that, conservation tillage with broad bed and furrow (BBF) and crop residues incorporation $\left(\mathrm{CT}_{2}\right)$, conservation tillage with $\mathrm{BBF}$ and crop residues retained on the surface $\left(\mathrm{CT}_{1}\right)$, conservation tillage with flatbed with incorporation of crop residues $\left(\mathrm{CT}_{4}\right)$ and conservation tillage with flatbed with crop residues retained on the surface $\left(\mathrm{CT}_{3}\right)$ significantly increased soil urease activity $(11.66,11.41,11.28$ and 10.99 $\mu \mathrm{g} \mathrm{NH} \mathrm{NH} \mathrm{g}_{4}-\mathrm{N}^{-1}$ day $^{-1}$, respectively), soil dehydrogenase activity $(32.02,31.64,31.49$ and $30.92 \mu \mathrm{g}$ TPF $\mathrm{g}^{-1}$ day $^{-1}$, respectively) and total phosphatase activity $(174.29,172.44$, 171.31 and $166.99 \mu \mathrm{g}$ PNP $\mathrm{g}^{-1} \mathrm{hr}^{-1}$, respectively)over conventional tillage with incorporation of crop residues $\left(\mathrm{CT}_{5}, 10.87 \mu \mathrm{g} \mathrm{NH}_{4}-\mathrm{N} \mathrm{g}^{-1}\right.$ day ${ }^{-1}, 28.92 \mu \mathrm{g}$ TPF g ${ }^{-1}$ day $^{-1}$ and $160.77 \mu \mathrm{g}$ PNP $\mathrm{g}^{-1} \mathrm{hr}^{-1}$, respectively) and conventional tillage without crop residues $\left(\mathrm{CT}_{6}, 10.10 \mu \mathrm{g} \mathrm{NH}_{4}-\mathrm{N} \mathrm{g}^{-1}\right.$ day $^{-1}, 26.35 \mu \mathrm{g}$ TPF g ${ }^{-1}$ day $^{-1}$ and $149.79 \mu \mathrm{g}$ PNP g $\mathrm{gr}^{-1}$, respectively). Similarly, all the tillage practices viz., $\mathrm{CT}_{1}, \mathrm{CT}_{2}, \mathrm{CT}_{3}, \mathrm{CT}_{4}$ and $\mathrm{CT}_{5}$ recorded significantly higher microbial biomass carbon (335.90, 328.76, 302.40, 333.84 and 293.95 $\mathrm{mg} \mathrm{kg} \mathrm{soil}{ }^{-1}$, respectively) and nitrogen $\left(14.12,13.69,12.59,13.90\right.$ and $12.24 \mathrm{mg} \mathrm{kg}$ soil $^{-1}$, respectively) over $\mathrm{CT}_{6}$ (260.64 and $10.83 \mathrm{mg} \mathrm{kg} \mathrm{soil}^{-1}$, respectively).
\end{abstract}

A B S T R A C T

Field experiments were carried out during 2014-15 and 2015-16 to know the effect of different tillage practices and cropping systems on biological quality of soils under rainfed

\section{Introduction}

Human efforts to produce ever-greater amounts of food leave their mark on our environment. Persistent use of conventional farming practices based on extensive tillage, especially when combined with removal or in situ burning of crop residues, have magnified soil erosion losses and the soil resource base has been steadily degraded (Montgomery 2007). Many soils have been worn down to their nadir for most soil parameters essential for effective, stable and sustainable crop production, including soil physical, chemical and biological factors. Tillage is an important management practice involving physical manipulation of soil for crop establishment. Optimization of tillage practices lead to improvement in soil health. Soil health is a dynamic and complex system, and its functions are mainly mediated by agricultural management practices (Doran and Zeiss, 2000). Intensive agricultural practices often leads to changes in soil health governing properties like, soil structure, aggregation, porosity, strength, hydraulic conductivity, infiltration, bulk density, soil moisture content, soil carbon content, soil microbial 
biomass, nitrogen and soil enzymes and their activities (Osunbitan et al., 2005 and Allen et al., 2011). Soil with better health and quality will be able to produce higher crop yield under favourable as well as extreme climatic conditions and soil health acts as a critical component for adaptation and mitigation of climate change effects by the crops (Congreves et al., 2015).

Crop management practices such as tillage systems and cropping systems can affect soil health. Karlen et al., (2013) observed that deep soil ploughing with mould board plough had significant negative impact on soil health and quality parameters. Conservation agricultural practices resulted in increased soil organic matter, soil structure due to maintenance of soil aggregates, reduced oxidation of soil organic matter compared to conventional tillage (Beare et al., 1994 and Halvorson et al., 2002). Similarly, crop diversification either in rotations/intercropping of legumes can also affects soil health by affecting carbon contents, due to the difference in chemical composition of different crop residues that are added to soil (Srinivasarao et al., 2013). These effects of either tillage or cropping systems on soil physical and chemical properties affect the microbial biomass and their activities and some other important processes such as organic matter decomposition and mediation of plant nutrient availability (Dick, 1992 and Balota et al., 2003).

Maintaining soil microbial biomass (SMB) and micro-flora activity and diversity is fundamental for sustainable agricultural management (Insam, 2001). Soil management influences soil microorganisms and soil microbial processes through changes in the quantity and quality of plant residues entering the soil, their seasonal and spatial distribution, the ratio between above- and below-ground inputs, and changes in nutrient inputs
(Christensen et al., 1994). The SMB reflects the soil's ability to store and cycle nutrients (C, N, P and S) and organic matter, and has a high turnover rate relative to the total soil organic matter (Dick 1992 and Carter et al., 1999). Due to its dynamic character, SMB responds to changes in soil management often before effects are measured in terms of organic $\mathrm{C}$ and $\mathrm{N}$ (Powlson and Jenkinson, 2005). The SMB plays an important role in physical stabilization of aggregates (Franzluebbers et al., 1999). General soil borne disease suppression is also related to total SMB, which competes with pathogens for resources or causes inhibition through more direct forms of antagonism (Weller et $a l ., 2002)$. The rate of organic $C$ input from plant biomass is generally considered the dominant factor controlling the amount of SMB in soil (Campbell et al., 2007). The total organic $\mathrm{C}$ pool expands or contracts due to changes in $\mathrm{C}$ inputs to the soil, the microbial pool also expands or contracts. A continuous, uniform supply of $\mathrm{C}$ from crop residues serves as an energy source for microorganisms.

Soil enzymes play an essential role in catalyzing the reactions necessary for organic matter decomposition and nutrient cycling. They are involved in energy transfer, environmental quality and crop productivity (Tabatabai, 2004). Management practices such as tillage, crop rotation/intercropping and their residue management may have diverse effects on various soil enzymes (Tabatabai, 2004) and in this way may alter the availability of plant nutrients. Enzymatic activities generally decrease with soil depth (Green et al., 2007). Conservation tillage and residue management practices increases stratification of enzyme activities in the soil profile.

It is hypothesized that conservation agriculture based tillage practices and diversified legume based cropping systems improve soil physical, chemical and biological properties and overall 
soil health, compared to conventional tillage. In India, the crop productivity is low and is not sustainable due to many reasons among them degrading of fertile soil is foremost factor. Hence, there is a need to sustain the crop productivity in a rainfed cropping system. In this backdrop, the studies were initiated with the sustainable application of conservation agriculture practices such as minimum soil disturbance, adequate soil cover or incorporation of crop residues and broad bed and furrow practices to foster soil biological improvements.

\section{Materials and Methods}

The field experiments were conducted on a fixed experimental site of conservation agriculture project at main Agricultural Research Station, University of Agricultural Sciences, Dharwad, Karnataka during 2014-15 and 2015-16 on neutral $\mathrm{pH}$ (7.4) vertic inceptisols with initial soil organic carbon $(0.52 \%)$. The experiment was replicated thrice and laid out in strip block design. The main plots consisting of 6 tillage practices $\mathrm{CT}_{1}$ Conservation tillage with $\mathrm{BBF}$ and crop residue retained on the surface, $\mathrm{CT}_{2}$ Conservation tillage with $\mathrm{BBF}$ and incorporation of crop residue, $\mathrm{CT}_{3}$ Conservation tillage with flat bed with crop residue retained on the surface, $\mathrm{CT}_{4}$ Conservation tillage with flat bed with incorporation of crop residue, $\mathrm{CT}_{5}$ Conventional tillage with crop residue incorporation and $\mathrm{CT}_{6}-$ Conventional tillage without crop residues. Sub plots consisting of 5 intercropping system viz., $\mathrm{CS}_{1}-$ Cotton + groundnut, $\mathrm{CS}_{2}-$ Cotton + soybean, $\mathrm{CS}_{3}-$ Pigeonpea + soybean, $\mathrm{CS}_{4}-$ Sole cotton and $\mathrm{CS}_{5}-$ Sole pigeonpea

The experiment was initiated during 2013-14 and conservation tillage plots were permanently maintained with bigger plot size of $15 \mathrm{~m}$ width and $9 \mathrm{~m}$ length. In convention plots, the land was ploughed with mould board plough once, cultivated and harrowed and soil was brought to fine tilth. In conservation tillage plots, minimum tillage for crop residue incorporation with rotovater two months before sowing and no tillage plots maintained with crop residue shredding and retention on the surface during $1^{\text {st }}$ week of April, till than residues were maintained on the surface. Intercrops such as Groundnut (GPBD 4) and soybean (Dsb 21) was sown at $30 \mathrm{~cm}$ spacing with the help of tractor drawn seed drill by skipping one row for every two rows and in a skipped row main crops such as cotton (Bindhas Hybrid) and pigeonpea (TS 3R) seeds were dibbled in the spacing of $90 \mathrm{~cm} \mathrm{x}$ $60 \mathrm{~cm}$ and $90 \mathrm{~cm}$ x $30 \mathrm{~cm}$, respectively. After every 6 rows $(180 \mathrm{~cm})$ a row was skipped for opening furrow $(30 \mathrm{~cm})$ which help to layout Broad Bed and Furrows (BBF) with $180 \mathrm{~cm}$ bed and $30 \mathrm{~cm}$ furrow immediately after sowing of the crops. All the recommended package of practices for cotton, pigeonpea, groundnut and soybean were followed to raise the healthy crops.

Paraquat a contact herbicide was sprayed to kill the established weeds at 10 days before sowing. The crop was weed free upto 30 days by pre-emergence application of pendimethalin (STOMP XTRA 38.7 CS) and later weeds were managed by post emergence application of quizalofop ethyl 5\% EC for cotton + groundnut, cotton + soybean and sole cotton and imazethapyr 10 SL for pigeonpea + soybean and sole pigeonpea at 30 DAS with the help of hand operated knapsack sprayer.

The data collected from the experiments were analyzed statistically following the procedure as described by Gomez and Gomez (1984). The level of significance used in ' $F$ ' tests was $\mathrm{P}=0.05$. The mean values of main plot, subplot interaction effects were separately subjected to Duncan's Multiple Range Test (DMRT) using the corresponding error mean 
sum of squares and degrees of freedom values under M-STAT - C program.

\section{Soil Microbial Biomass Carbon (SMB-C) and Nitrogen (SMB-N)}

Soil microbial biomass carbon and nitrogen was estimated by fumigation and extraction method (Carter, 1991) by using following formula.

Ninhydrin reactive $\mathrm{N}$ in fumigated soil Ninhydrin reactive $\mathrm{N}$ in unfumigated soil MBCg of soil = ---------------- x 24

Ninhydrin reactive $\mathrm{N}$ in fumigated soil Ninhydrin reactive $\mathrm{N}$ in unfumigated soil MBNg of soil =

$$
\text { Weight of soil sample }
$$

Soil urease activity at 75 DAS: Urease activity of the soil was determined by following the procedure as given by Pancholy and Rice, 1973.

Dehydrogenase activity at 75 DAS: Dehydrogenase activity of the soil sample was determined by following the procedure as described by Casida et al., (1964).

Phosphatase activity at 75 DAS: Phosphatase activity of soil sample was determined by following the procedure of Eivazi and Tabatabai (1979).

\section{Results and Discussion}

\section{Soil microbial biomass carbon (SMB-C)}

Pooled data on SMB-C showed that, all the conservation tillage practices $\left(\mathrm{CT}_{1}, \mathrm{CT}_{2}, \mathrm{CT}_{3}\right.$ and CT4) and conventional tillage with incorporation of crop residue $\left(\mathrm{CT}_{5}\right)$ recorded significantly higher SMB-C (335.90, 328.76, $302.40,333.84$ and $293.95 \mathrm{mg} \mathrm{kg}^{-1}$ of soil, respectively) as compared to conventional tillage without crop residues $\left(\mathrm{CT}_{6}, 260.64 \mathrm{mg}\right.$ $\mathrm{kg}^{-1}$ of soil). Over the years SMB-C did not have any significant effect by cropping systems and ranged from 280.47 to $337.98 \mathrm{mg}$ $\mathrm{kg}^{-1}$ of soil (Table 3 ).

The interaction effects due to tillage practices and cropping systems had significant influence on SMB-C. Among different combinations, no tillage with $\mathrm{BBF}$ and crop residues retained on the surface in intercropping of pigeonpea + soybean, reduced tillage with flatbed with incorporation of crop residues in intercropping of pigeonpea + soybean, reduced tillage with $\mathrm{BBF}$ and incorporation of crop residue in intercropping of pigeonpea + soybean, reduced tillage with flatbed with incorporation of crop residues in intercropping of cotton + groundnut, reduced tillage with $\mathrm{BBF}$ and incorporation of crop residues in intercropping of cotton + groundnut and no tillage with BBF and crop residues retained on the surface in intercropping of cotton + groundnut recorded significantly higher SMB-C (364.00, 362.00, $355.20,354.00,351.20$ and $350.32 \mathrm{mg} \mathrm{kg}^{-1}$ of soil, respectively) and these were on par with rest of the treatment combinations except conventional tillage without crop residues with sole cotton $\left(229.60 \mathrm{mg} \mathrm{kg}^{-1}\right.$ of soil) and sole pigeonpea (243.60 mg kg-1 of soil) (Table $1)$.

\section{Soil microbial biomass nitrogen (SMB-N)}

Tillage practices had significant influence on SMB-N. All the conservation tillage practices $\left(\mathrm{CT}_{1}, \mathrm{CT}_{2}, \mathrm{CT}_{3}\right.$ and $\left.\mathrm{CT} 4\right)$ and conventional tillage with incorporation of crop residue $\left(\mathrm{CT}_{5}\right)$ recorded significantly higher SMB-N (14.12, 13.69, 12.59, 13.90 and $12.24 \mathrm{mg} \mathrm{kg}^{-1}$ of soil, respectively) as compared to conventional tillage without crop residue $\left(\mathrm{CT}_{6}, 10.83 \mathrm{mg} \mathrm{kg}^{-1}\right.$ of soil). The pooled data on SMB-N did not have any significant effect 
by cropping systems and ranged from 11.69 to $13.88 \mathrm{mg} \mathrm{kg}^{-1}$ of soil. Among different combinations, no tillage with BBF and crop residue retained on the surface in intercropping of pigeonpea + soybean, reduced tillage with flatbed with incorporation of crop residues in intercropping of pigeonpea + soybean and reduced tillage with flatbed with incorporation of crop residues in intercropping of cotton + groundnut recorded significantly higher SMB-N (14.97, 14.88 and $14.75 \mathrm{mg} \mathrm{kg}^{-1}$ of soil, respectively) and they were on par with rest of the treatment combinations except conventional tillage without crop residues with sole cotton $(9.57$ $\mathrm{mg} \mathrm{kg}{ }^{-1}$ of soil) and sole pigeonpea (10.53 mg $\mathrm{kg}^{-1}$ of soil) (Table 1).

The improvement in SMB- $\mathrm{C}$ and $\mathrm{N}$ is mainly due to rate of organic carbon input from plant biomass which is the dominant factor controlling the amount of SMB in soil. Reduction in loss of soil organic carbon in conservation tillage and continuous, uniform supply of carbon from crop residues serves as an energy source for microorganisms.

Minimum soil disturbance under conservation tillage and crop residue retention/incorporation tend to better aggregation in soil might be attributed to increase in soil organic carbon as well as SMB-C and N.

Association of improved aggregation and increase in organic and microbial biomass carbon was reported elsewhere (Sasal et al., 2006; Ozpinar and Cay, 2006). Protection of the surface layer by crop residue mulch against the action of falling raindrops, exposure to sunlight and reduction in loss of SOC through wind and water erosion might be the other factors to improvement in the soil aggregation, greater mean weight diameter and geometric mean diameter owing to significantly higher soil organic carbon and microbial biomass carbon. And also more SOC and SMB-C and $\mathrm{N}$ in the conservation tillage with residue was arguably caused by less oxidation of organic matter due to less disturbance of soil by tillage, higher substrates available for microorganism growth, better soil physical conditions and higher water retention (Franzluebbers et al., 1999; Spedding et al., 2004 and Alvear et al., 2005).

\section{Soil urease activity}

The results obtained with respect to soil urease activity as influenced by different tillage practices and cropping systems is presented in Table 2.

Tillage practices had a significant effect on soil urease activity. Significantly higher soil urease activity $\left(11.66 \mu \mathrm{g} \mathrm{NH}_{4}-\mathrm{N} \mathrm{g}^{-1}\right.$ day $\left.^{-1}\right)$ was recorded in reduced tillage with $\mathrm{BBF}$ and incorporation of crop residues $\left(\mathrm{CT}_{2}\right)$ over conventional tillage with crop residues of incorporation $\left(\mathrm{CT}_{5}\right)$ and conventional tillage without crop residues $\left(\mathrm{CT}_{6}\right)$ (10.87 and 10.10 $\mu \mathrm{g} \mathrm{NH}_{4}-\mathrm{N} \mathrm{g}^{-1}$ day ${ }^{-1}$, respectively).

However, it was on par with no tillage with BBF and crop residue retained on the surface $\left(\mathrm{CT}_{1}, 11.41 \mu \mathrm{g} \mathrm{NH}_{4}-\mathrm{N} \mathrm{g}^{-1}\right.$ day $\left.^{-1}\right)$ and reduced tillage with flatbed with incorporation of crop residue $\left(\mathrm{CT}_{4}, 11.28 \mu \mathrm{g} \mathrm{NH}_{4}-\mathrm{N} \mathrm{g}^{-1}\right.$ day $\left.^{-1}\right)$. The pooled data on soil urease activity did not have any significant effect by cropping systems and ranged from 10.81 to $11.28 \mu \mathrm{g}$ $\mathrm{NH}_{4}-\mathrm{N} \mathrm{g}^{-1}$ day $^{-1}$.

The interaction effects due to tillage practices and cropping systems had significant influence on soil urease activity. Among different combinations, reduced tillage with BBF and incorporation of crop residue in intercropping of pigeonpea + soybean recorded significantly higher soil urease activity $\left(11.86 \mu \mathrm{g} \mathrm{NH}_{4}-\mathrm{N} \mathrm{g}^{-1}\right.$ day $\left.^{-1}\right)$ over rest of the treatment combinations. 
Table.1 Soil microbial biomass carbon and nitrogen (pooled data of 2014-16) as influenced by different conservation tillage practices and intercropping systems

Treatment

Main plot: Tillage systems (CT)

$\mathrm{CT}_{1}$ - No tillage with BBF and crop residues retained on the surface

$\mathrm{CT}_{2}$ - Reduced tillage with BBF and incorporation of crop residues

$\mathrm{CT}_{3}$ - No tillage with flat bed with crop residues retained on the surface

$\mathrm{CT}_{4}$ - Reduced tillage with flat bed with incorporation of crop residues

$\mathrm{CT}_{5}$ - Conventional tillage with crop residues incorporation

$\mathrm{CT}_{6}$ - Conventional tillage without crop residues

S.Em \pm

Sub plot: Cropping systems (CS)

$\mathrm{CS}_{1}-$ Cotton + Groundnut

$\mathrm{CS}_{2}-$ Cotton + Soybean

$\mathrm{CS}_{3}$ - Pigeonpea + Soybean

$\mathrm{CS}_{4}-$ Sole cotton

$\mathrm{CS}_{5}-$ Sole pigeonpea

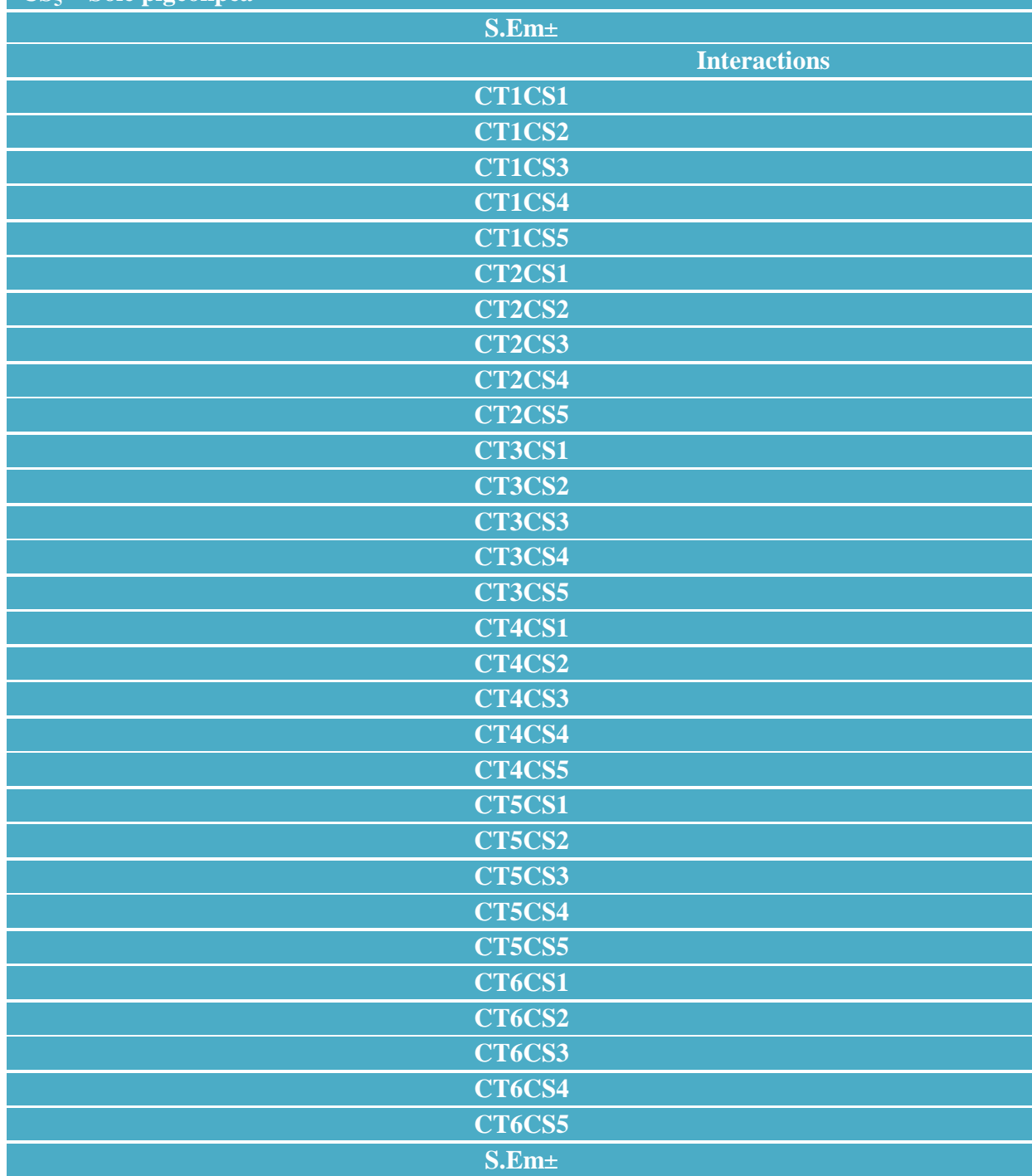

\section{SMB-C}

(mg kg soil ${ }^{-1}$ )

335.90a

$328.76 \mathrm{a}$

302.40a

$333.84 a$

293.95a

260.64b

63.79

$325.05 \mathrm{a}$

308.38a

$337.98 \mathrm{a}$

280.47 a

294.37a

32.84

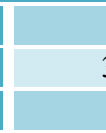

$350.32 a$

333.60ab

$364.00 \mathrm{a}$

$306.00 \mathrm{a}-\mathrm{c}$

$325.60 \mathrm{a}-\mathrm{c}$

$351.20 \mathrm{a}$

$326.00 \mathrm{a}-\mathrm{c}$

$355.20 \mathrm{a}$

$300.40 \mathrm{a}-\mathrm{c}$

311.00 a-c

$317.20 \mathrm{a}-\mathrm{c}$

297.60 a-c

327.20 a-c

278.80 a-c

291.20 a-c

$354.00 \mathrm{a}$

332.40ab

$362.00 \mathrm{a}$

304.40 a-c

316.40 a-c

306.40 a-c

295.87 a-c

$325.47 \mathrm{a}-\mathrm{c}$

$263.60 \mathrm{a}-\mathrm{c}$

278.40 a-c

271.20 a-c

264.80 a-c

$294.00 \mathrm{a}-\mathrm{c}$

229.60c

$243.60 \mathrm{bc}$

46.31
SMB-N

(mg kg soill ${ }^{-1}$ )

$14.12 \mathrm{a}$

$13.69 \mathrm{a}$

$12.59 \mathrm{a}$

$13.90 \mathrm{a}$

$12.24 \mathrm{a}$

$10.83 \mathrm{~b}$

2.60

$13.49 \mathrm{a}$

$12.85 \mathrm{a}$

$13.88 \mathrm{a}$

$11.69 \mathrm{a}$

$12.57 \mathrm{a}$

1.34

$14.60 \mathrm{ab}$

13.90ab

$14.97 \mathrm{a}$

$12.75 a-c$

14.38ab

14.63ab

$13.58 \mathrm{a}-\mathrm{c}$

14.60ab

$12.52 \mathrm{a}-\mathrm{c}$

$13.11 \mathrm{a}-\mathrm{c}$

$13.22 \mathrm{a}-\mathrm{c}$

$12.40 \mathrm{a}-\mathrm{c}$

$13.43 \mathrm{a}-\mathrm{c}$

$11.62 \mathrm{a}-\mathrm{c}$

$12.28 \mathrm{a}-\mathrm{c}$

$14.75 \mathrm{a}$

$13.85 \mathrm{ab}$

$14.88 \mathrm{a}$

$12.68 \mathrm{a}-\mathrm{c}$

$13.33 \mathrm{a}-\mathrm{c}$

12.77 a-c

$12.33 \mathrm{a}-\mathrm{c}$

13.36 a-c

10.98 a-c

11.75 a-c

$10.97 \mathrm{a}-\mathrm{c}$

$11.03 \mathrm{a}-\mathrm{c}$

$12.05 \mathrm{a}-\mathrm{c}$

$9.57 \mathrm{c}$

$10.53 \mathrm{bc}$

1.87

SBM-C - Soil microbial biomass carbon and SBM-N- Soil microbial biomass nitrogen 
Table.2 Soil enzyme activity at 75 DAS (Pooled of 2014-16) as influenced by different conservation tillage practices and intercropping systems

\section{Treatment}

Main plot: Tillage systems (CT)

$\mathrm{CT}_{1}$ - No tillage with BBF and crop residues retained on the surface

$\mathrm{CT}_{2}$ - Reduced tillage with BBF and incorporation of crop residues

$\mathrm{CT}_{3}$ - No tillage with flat bed with crop residues retained on the surface

$\mathrm{CT}_{4}$ - Reduced tillage with flat bed with incorporation of crop residues

$\mathrm{CT}_{5}$ - Conventional tillage with crop residues incorporation

$\mathrm{CT}_{6}$ - Conventional tillage without crop residues

\begin{tabular}{|l|}
\hline \multicolumn{1}{|c|}{ S.Em \pm} \\
\hline Sub plot: Cropping systems (CS) \\
\hline $\mathrm{CS}_{1}-$ Cotton + Groundnut \\
\hline $\mathrm{CS}_{2}$ - Cotton + Soybean \\
\hline $\mathrm{CS}_{3}$ - Pigeonpea + Soybean \\
\hline $\mathrm{CS}_{4}-$ Sole cotton \\
\hline $\mathrm{CS}_{5}-$ Sole pigeonpea \\
\hline
\end{tabular}

Interactions

\begin{tabular}{|c|c|c|c|}
\hline $\mathrm{CT}_{1} \mathrm{CS}_{1}$ & $11.38 \mathrm{a}-\mathrm{f}$ & $31.48 \mathrm{a}-\mathrm{c}$ & $180.51 b$ \\
\hline $\mathrm{CT}_{1} \mathrm{CS}_{2}$ & $11.46 \mathrm{a}-\mathrm{e}$ & $30.57 c-f$ & $170.39 \mathrm{ef}$ \\
\hline $\mathrm{CT}_{1} \mathrm{CS}_{3}$ & 11.76ab & $32.29 \mathrm{ab}$ & $173.21 \mathrm{c}-\mathrm{e}$ \\
\hline $\mathrm{CT}_{1} \mathrm{CS}_{4}$ & $11.07 \mathrm{~d}-\mathrm{h}$ & $31.64 a-c$ & $166.52 \mathrm{~g}-\mathrm{i}$ \\
\hline $\mathrm{CT}_{1} \mathrm{CS}_{5}$ & $11.38 \mathrm{a}-\mathrm{f}$ & $32.23 \mathrm{ab}$ & $171.58 \mathrm{~d}-\mathrm{f}$ \\
\hline $\mathrm{CT}_{2} \mathrm{CS}_{1}$ & 11.78ab & $32.54 \mathrm{a}$ & $184.97 \mathrm{a}$ \\
\hline $\mathrm{CT}_{2} \mathrm{CS}_{2}$ & $11.62 \mathrm{a}-\mathrm{d}$ & $31.22 \mathrm{~b}-\mathrm{e}$ & $171.58 \mathrm{~d}-\mathrm{f}$ \\
\hline $\mathrm{CT}_{2} \mathrm{CS}_{3}$ & $11.86 \mathrm{a}$ & $32.29 \mathrm{ab}$ & $174.55 \mathrm{~cd}$ \\
\hline $\mathrm{CT}_{2} \mathrm{CS}_{4}$ & $11.38 \mathrm{a}-\mathrm{f}$ & 31.98ab & $167.86 f-h$ \\
\hline $\mathrm{CT}_{2} \mathrm{CS}_{5}$ & $11.65 \mathrm{a}-\mathrm{c}$ & 32.09ab & $172.47 \mathrm{c}-\mathrm{e}$ \\
\hline $\mathrm{CT}_{3} \mathrm{CS}_{1}$ & $11.11 \mathrm{c}-\mathrm{h}$ & 30.61c-f & $175.60 \mathrm{c}$ \\
\hline $\mathrm{CT}_{3} \mathrm{CS}_{2}$ & $11.04 \mathrm{e}-\mathrm{h}$ & $30.15 \mathrm{e}-\mathrm{g}$ & $162.65 \mathrm{j}-\mathrm{m}$ \\
\hline $\mathrm{CT}_{3} \mathrm{CS}_{3}$ & $11.10 \mathrm{c}-\mathrm{h}$ & $31.14 b-e$ & $170.09 \mathrm{e}-\mathrm{g}$ \\
\hline $\mathrm{CT}_{3} \mathrm{CS}_{4}$ & 10.86f-i & $31.31 \mathrm{~b}-\mathrm{d}$ & $160.86 \mathrm{k}-\mathrm{m}$ \\
\hline $\mathrm{CT}_{3} \mathrm{CS}_{5}$ & $10.83 f-i$ & $31.41 \mathrm{a}-\mathrm{d}$ & $165.77-\mathrm{j}$ \\
\hline $\mathrm{CT}_{4} \mathrm{CS}_{1}$ & 11.35a-f & $31.60 \mathrm{a}-\mathrm{c}$ & $179.02 b$ \\
\hline $\mathrm{CT}_{4} \mathrm{CS}_{2}$ & $11.24 \mathrm{~b}-\mathrm{g}$ & $30.35 \mathrm{~d}-\mathrm{f}$ & $170.24 \mathrm{ef}$ \\
\hline $\mathrm{CT}_{4} \mathrm{CS}_{3}$ & $11.44 \mathrm{a}-\mathrm{e}$ & $31.55 \mathrm{a}-\mathrm{c}$ & $173.21 \mathrm{c}-\mathrm{e}$ \\
\hline $\mathrm{CT}_{4} \mathrm{CS}_{4}$ & $11.16 \mathrm{c}-\mathrm{h}$ & $31.98 \mathrm{ab}$ & $164.43 \mathrm{~h}-\mathrm{k}$ \\
\hline $\mathrm{CT}_{4} \mathrm{CS}_{5}$ & $11.20 \mathrm{c}-\mathrm{h}$ & $31.96 \mathrm{ab}$ & $169.64 \mathrm{e}-\mathrm{g}$ \\
\hline $\mathrm{CT}_{5} \mathrm{CS}_{1}$ & $11.00 \mathrm{e}-\mathrm{h}$ & $29.24 \mathrm{gh}$ & $170.9 d-f$ \\
\hline $\mathrm{CT}_{5} \mathrm{CS}_{2}$ & $10.66 \mathrm{~h}-\mathrm{j}$ & 28.51hi & $159.67 \mathrm{~m}$ \\
\hline $\mathrm{CT}_{5} \mathrm{CS}_{3}$ & $11.12 \mathrm{c}-\mathrm{h}$ & 29.70fg & $160.421 \mathrm{~m}$ \\
\hline $\mathrm{CT}_{5} \mathrm{CS}_{4}$ & $10.69 \mathrm{~g}-\mathrm{j}$ & $27.88 \mathrm{ij}$ & 149.11op \\
\hline $\mathrm{CT}_{5} \mathrm{CS}_{5}$ & $10.90 \mathrm{e}-\mathrm{i}$ & $29.98 \mathrm{fg}$ & $163.69 \mathrm{i}-1$ \\
\hline $\mathrm{CT}_{6} \mathrm{CS}_{1}$ & $10.45 \mathrm{ij}$ & 26.111 & $155.06 n$ \\
\hline $\mathrm{CT}_{6} \mathrm{CS}_{2}$ & $9.74 \mathrm{k}$ & 25.571 & $146.73 p$ \\
\hline $\mathrm{CT}_{6} \mathrm{CS}_{3}$ & $10.39 \mathrm{ij}$ & $27.43 \mathrm{jk}$ & $154.32 \mathrm{n}$ \\
\hline $\mathrm{CT}_{6} \mathrm{CS}_{4}$ & $9.71 \mathrm{k}$ & 26.131 & $140.63 q$ \\
\hline $\mathrm{CT}_{6} \mathrm{CS}_{5}$ & $10.20 \mathrm{jk}$ & $26.50 \mathrm{kl}$ & $152.23 \mathrm{no}$ \\
\hline S.Em. \pm & 0.25 & 0.53 & 1.85 \\
\hline
\end{tabular}

SAU- Soil urease activity, SDA - Soil dehydrogenase activity and Total phosphatase activity

\begin{tabular}{|c|c|c|c|}
\hline $\mathrm{CT}_{1} \mathrm{CS}_{1}$ & $11.38 \mathrm{a}-\mathrm{f}$ & $31.48 \mathrm{a}-\mathrm{c}$ & $180.51 b$ \\
\hline $\mathrm{CT}_{1} \mathrm{CS}_{2}$ & $11.46 \mathrm{a}-\mathrm{e}$ & $30.57 c-f$ & $170.39 \mathrm{ef}$ \\
\hline $\mathrm{CT}_{1} \mathrm{CS}_{3}$ & $11.76 \mathrm{ab}$ & $32.29 \mathrm{ab}$ & $173.21 \mathrm{c}-\mathrm{e}$ \\
\hline $\mathrm{CT}_{1} \mathrm{CS}_{4}$ & $11.07 \mathrm{~d}-\mathrm{h}$ & $31.64 \mathrm{a}-\mathrm{c}$ & $166.52 \mathrm{~g}-\mathrm{i}$ \\
\hline $\mathrm{CT}_{1} \mathrm{CS}_{5}$ & $11.38 \mathrm{a}-\mathrm{f}$ & $32.23 \mathrm{ab}$ & $171.58 \mathrm{~d}-\mathrm{f}$ \\
\hline $\mathrm{CT}_{2} \mathrm{CS}_{1}$ & 11.78ab & $32.54 \mathrm{a}$ & $184.97 \mathrm{a}$ \\
\hline $\mathrm{CT}_{2} \mathrm{CS}_{2}$ & $11.62 \mathrm{a}-\mathrm{d}$ & $31.22 \mathrm{~b}-\mathrm{e}$ & $171.58 \mathrm{~d}-\mathrm{f}$ \\
\hline $\mathrm{CT}_{2} \mathrm{CS}_{3}$ & $11.86 \mathrm{a}$ & $32.29 \mathrm{ab}$ & $174.55 \mathrm{~cd}$ \\
\hline $\mathrm{CT}_{2} \mathrm{CS}_{4}$ & $11.38 \mathrm{a}-\mathrm{f}$ & 31.98ab & $167.86 f-h$ \\
\hline $\mathrm{CT}_{2} \mathrm{CS}_{5}$ & $11.65 a-c$ & $32.09 \mathrm{ab}$ & $172.47 \mathrm{c}-\mathrm{e}$ \\
\hline $\mathrm{CT}_{3} \mathrm{CS}_{1}$ & $11.11 \mathrm{c}-\mathrm{h}$ & $30.61 \mathrm{c}-\mathrm{f}$ & $175.60 \mathrm{c}$ \\
\hline $\mathrm{CT}_{3} \mathrm{CS}_{2}$ & $11.04 \mathrm{e}-\mathrm{h}$ & $30.15 \mathrm{e}-\mathrm{g}$ & $162.65 \mathrm{j}-\mathrm{m}$ \\
\hline $\mathrm{CT}_{3} \mathrm{CS}_{3}$ & $11.10 \mathrm{c}-\mathrm{h}$ & $31.14 b-e$ & $170.09 \mathrm{e}-\mathrm{g}$ \\
\hline $\mathrm{CT}_{3} \mathrm{CS}_{4}$ & 10.86f-i & $31.31 \mathrm{~b}-\mathrm{d}$ & $160.86 \mathrm{k}-\mathrm{m}$ \\
\hline $\mathrm{CT}_{3} \mathrm{CS}_{5}$ & $10.83 f-i$ & $31.41 \mathrm{a}-\mathrm{d}$ & $165.77-\mathrm{j}$ \\
\hline $\mathrm{CT}_{4} \mathrm{CS}_{1}$ & 11.35a-f & $31.60 \mathrm{a}-\mathrm{c}$ & $179.02 b$ \\
\hline $\mathrm{CT}_{4} \mathrm{CS}_{2}$ & $11.24 \mathrm{~b}-\mathrm{g}$ & $30.35 d-f$ & $170.24 \mathrm{ef}$ \\
\hline $\mathrm{CT}_{4} \mathrm{CS}_{3}$ & $11.44 \mathrm{a}-\mathrm{e}$ & $31.55 \mathrm{a}-\mathrm{c}$ & $173.21 \mathrm{c}-\mathrm{e}$ \\
\hline $\mathrm{CT}_{4} \mathrm{CS}_{4}$ & $11.16 \mathrm{c}-\mathrm{h}$ & 31.98ab & $164.43 \mathrm{~h}-\mathrm{k}$ \\
\hline $\mathrm{CT}_{4} \mathrm{CS}_{5}$ & $11.20 \mathrm{c}-\mathrm{h}$ & 31.96ab & $169.64 \mathrm{e}-\mathrm{g}$ \\
\hline $\mathrm{CT}_{5} \mathrm{CS}_{1}$ & $11.00 \mathrm{e}-\mathrm{h}$ & $29.24 \mathrm{gh}$ & $170.9 d-f$ \\
\hline $\mathrm{CT}_{5} \mathrm{CS}_{2}$ & 10.66h-j & 28.51hi & $159.67 \mathrm{~m}$ \\
\hline $\mathrm{CT}_{5} \mathrm{CS}_{3}$ & $11.12 \mathrm{c}-\mathrm{h}$ & 29.70fg & $160.421 \mathrm{~m}$ \\
\hline $\mathrm{CT}_{5} \mathrm{CS}_{4}$ & $10.69 \mathrm{~g}-\mathrm{j}$ & $27.88 \mathrm{ij}$ & 149.11op \\
\hline $\mathrm{CT}_{5} \mathrm{CS}_{5}$ & $10.90 \mathrm{e}-\mathrm{i}$ & $29.98 \mathrm{fg}$ & $163.69 \mathrm{i}-1$ \\
\hline $\mathrm{CT}_{6} \mathrm{CS}_{1}$ & $10.45 \mathrm{ij}$ & 26.111 & $155.06 n$ \\
\hline $\mathrm{CT}_{6} \mathrm{CS}_{2}$ & $9.74 \mathrm{k}$ & 25.571 & $146.73 p$ \\
\hline $\mathrm{CT}_{6} \mathrm{CS}_{3}$ & $10.39 \mathrm{ij}$ & $27.43 \mathrm{jk}$ & $154.32 n$ \\
\hline $\mathrm{CT}_{6} \mathrm{CS}_{4}$ & $9.71 \mathrm{k}$ & 26.131 & $140.63 q$ \\
\hline $\mathrm{CT}_{6} \mathrm{CS}_{5}$ & $10.20 \mathrm{jk}$ & $26.50 \mathrm{kl}$ & $152.23 \mathrm{no}$ \\
\hline S.Em. \pm & 0.25 & 0.53 & 1.85 \\
\hline
\end{tabular}

\begin{tabular}{|c|c|c|}
\hline $11.18 \mathrm{a}$ & $30.26 \mathrm{a}$ & $174.36 \mathrm{a}$ \\
\hline $10.96 \mathrm{a}$ & $29.40 \mathrm{a}$ & $163.54 \mathrm{ab}$ \\
\hline $11.28 \mathrm{a}$ & $30.73 \mathrm{a}$ & $167.63 \mathrm{ab}$ \\
\hline $10.81 \mathrm{a}$ & $30.15 \mathrm{a}$ & $158.23 \mathrm{ab}$ \\
\hline $11.03 \mathrm{a}$ & $30.69 \mathrm{a}$ & $165.90 \mathrm{ab}$ \\
\hline $\mathbf{0 . 3 5}$ & $\mathbf{0 . 6 6}$ & $\mathbf{4 . 0 6}$ \\
\hline
\end{tabular}


Table. 3 Crop residue applied to the residue plots $\left(\mathrm{t} \mathrm{ha}^{-1}\right)$

\begin{tabular}{|c|c|c|c|c|c|c|c|c|c|c|}
\hline $\begin{array}{c}\text { Tillage/ } \\
\text { Cropping } \\
\text { systems }\end{array}$ & $\mathrm{CS}_{1}$ & $\mathrm{CS}_{2}$ & $\mathrm{CS}_{3}$ & $\mathrm{CS}_{4}$ & $\mathrm{CS}_{5}$ & $\mathrm{CS}_{1}$ & $\mathrm{CS}_{2}$ & $\mathrm{CS}_{3}$ & $\mathrm{CS}_{4}$ & $\mathrm{CS}_{5}$ \\
\hline $\mathrm{CT}_{1}$ & 5.16 & 3.81 & 7.07 & 3.29 & 5.73 & 4.43 & 3.08 & 4.09 & 2.73 & 3.29 \\
\hline $\mathrm{CT}_{2}$ & 5.17 & 3.76 & 7.03 & 3.32 & 5.64 & 4.54 & 3.05 & 4.03 & 2.76 & 3.34 \\
\hline $\mathrm{CT}_{3}$ & 4.81 & 3.55 & 6.65 & 3.37 & 5.40 & 4.19 & 2.67 & 3.45 & 2.54 & 3.04 \\
\hline $\mathrm{CT}_{4}$ & 4.99 & 3.60 & 6.75 & 3.24 & 5.35 & 4.23 & 2.70 & 3.58 & 2.64 & 3.13 \\
\hline $\mathrm{CT}$ & 4.67 & 3.36 & 6.31 & 3.08 & 5.21 & 4.00 & 2.62 & 3.38 & 2.68 & 3.05 \\
\hline
\end{tabular}

However, it was on par with reduced tillage with BBF with incorporation of crop residues in intercropping of cotton + groundnut (11.78 $\mu \mathrm{g} \mathrm{NH}_{4}-\mathrm{N} \mathrm{g}^{-1}$ day $^{-1}$ ), no tillage with BBF with crop residues retained on the surface in intercropping of pigeonpea + soybean (11.76 $\mu \mathrm{g} \mathrm{NH}_{4}-\mathrm{N} \mathrm{g}^{-1}$ day $^{-1}$ ), reduced tillage with $\mathrm{BBF}$ and incorporation of crop residue with sole pigeonpea $\left(11.65 \mu \mathrm{g} \mathrm{NH}_{4}-\mathrm{N} \mathrm{g}^{-1}\right.$ day $\left.^{-1}\right)$, reduced tillage with $\mathrm{BBF}$ and incorporation of crop residues in intercropping of cotton + soybean (11.62 $\left.\mu \mathrm{g} \quad \mathrm{NH}_{4}-\mathrm{N} \quad \mathrm{g}^{-1} \mathrm{day}^{-1}\right)$, no tillage with BBF and crop residue retained on the surface in intercropping of cotton + soybean $\left(11.46 \mu \mathrm{g} \mathrm{NH}_{4}-\mathrm{N} \mathrm{g}^{-1}\right.$ day $\left.^{-1}\right)$, reduced tillage with flatbed with incorporation of crop residue with intercropping of pigeonpea + soybean (11.44 $\mu \mathrm{g} \quad \mathrm{NH}_{4}-\mathrm{N} \mathrm{g}^{-1}$ day $^{-1}$ ), no tillage with $\mathrm{BBF}$ and crop residue retained on the surface with intercropping of cotton + groundnut (11.38 $\mu \mathrm{g} \mathrm{NH}_{4}-\mathrm{N} \mathrm{g}^{-1}$ day $^{-1}$ ), no tillage with $\mathrm{BBF}$ and crop residue retained on the surface with sole pigeonpea (11.38 $\mu \mathrm{g}$ $\mathrm{NH}_{4}-\mathrm{N} \mathrm{g}^{-1}$ day $^{-1}$ ), reduced tillage with BBF and incorporation of crop residue with sole cotton (11.38 $\mu \mathrm{g} \quad \mathrm{NH}_{4}-\mathrm{N} \quad \mathrm{g}^{-1}$ day $^{-1}$ ) and reduced tillage with flatbed and incorporation of crop residue with intercropping of cotton + groundnut $\left(11.35 \mu \mathrm{g} \quad \mathrm{NH}_{4}-\mathrm{N} \quad \mathrm{g}^{-1}\right.$ day $\left.^{-1}\right)$. Similarly, conventional tillage without crop residue with sole cotton and conventional tillage without crop residue and intercropping of cotton + soybean recorded significantly lower soil urease activity $(9.71$ and $9.74 \mu \mathrm{g}$ $\mathrm{NH}_{4}-\mathrm{N} \mathrm{g}^{-1}$ day ${ }^{-1}$, respectively).

\section{Soil dehydrogenase activity}

Tillage practices and cropping systems had significant effect on soil dehydrogenase activity (Table 2). With respect to tillage practices, all the conservation tillage practices $\left(\mathrm{CT}_{1}, \mathrm{CT}_{2}, \mathrm{CT}_{3}\right.$ and $\left.\mathrm{CT}_{4}\right)$ recorded significantly higher soil dehydrogenase activity $(31.64,32.02,30.92$ and $31.49 \mu \mathrm{g}$ TPF $\mathrm{g}^{-1}$ day $^{-1}$, respectively) as compared to conventional tillage with $\left(\mathrm{CT}_{5}, 28.92 \mu \mathrm{g}\right.$ TPF $\mathrm{g}^{-1}$ day $\left.^{-1}\right)$ and without crop residue $\left(\mathrm{CT}_{6}\right.$, $26.35 \mu \mathrm{g}$ TPF $\mathrm{g}^{-1}$ day $^{-1}$ ). The pooled data on soil dehydrogenase activity did not have any significant effect by cropping systems and ranged from 30.15 to $30.73 \mu \mathrm{g}_{\text {TPF g }}{ }^{-1}$ day $^{-1}$.

The interaction effects due to tillage practices and cropping systems had significant influence on soil dehydrogenase activity. Among different combinations, reduced tillage with $\mathrm{BBF}$ and incorporation of crop residue with intercropping of cotton + groundnut recorded significantly higher soil urease activity (32.54 $\mu \mathrm{g}$ TPF g $\mathrm{g}^{-1}$ day $\left.^{-1}\right)$ over rest of the treatment combinations.

However, it was on par with reduced tillage with BBF with incorporation of crop residues with intercropping of pigeonpea + soybean (32.29 $\mu \mathrm{g} \mathrm{TPF} \mathrm{g}^{-1}$ day $^{-1}$ ), no tillage with BBF with crop residues retained on the surface with intercropping of pigeonpea + soybean (32.29 $\mu \mathrm{g} \mathrm{TPF} \mathrm{g}^{-1}$ day $^{-1}$ ), no tillage with BBF and crop residues retained on the surface with 
sole pigeonpea (32.23 $\mu \mathrm{g}$ TPF $\mathrm{g}^{-1}$ day $^{-1}$ ), reduced tillage with $\mathrm{BBF}$ and incorporation of crop residues with sole pigeonpea (32.09 $\mu \mathrm{g}$ TPF $\mathrm{g}^{-1}$ day $^{-1}$ ), reduced tillage with BBF and incorporation of crop residues with sole cotton (31.98 $\mu \mathrm{g}$ TPF $\mathrm{g}^{-1}$ day $^{-1}$ ), no tillage with flat bed with incorporation of crop residues with sole cotton $\left(31.98 \mu \mathrm{g}\right.$ TPF $\mathrm{g}^{-1}$ day $\left.^{-1}\right)$, sole pigeonpea $\left(31.96 \mu \mathrm{g}\right.$ TPF $\mathrm{g}^{-1}$ day $\left.{ }^{1}\right)$, no tillage with $\mathrm{BBF}$ and crop residues retained on the surface with sole cotton (31.64 $\mu \mathrm{g}$ TPF $\mathrm{g}^{-1}$ day $^{-1}$ ), reduced tillage with BBF and incorporation of crop residues with sole cotton (31.60 $\mu \mathrm{g}$ TPF $\mathrm{g}^{-1}$ day $^{-1}$ ), reduced tillage with flatbed with incorporation of crop residue with intercropping of pigeonpea + soybean (31.55 $\mu \mathrm{g}$ TPF $\mathrm{g}^{-1}$ day $^{-1}$ ) and no tillage with $\mathrm{BBF}$ and crop residue retained on the surface with intercropping of cotton + groundnut $\left(31.48 \mu \mathrm{g}\right.$ TPF $\left.\mathrm{g}^{-1} \mathrm{day}^{-1}\right)$. Similarly, conventional tillage without crop residue with intercropping of cotton + soybean, cotton + groundnut and sole cotton recorded significantly lower soil dehydrogenase activity (25.57, 26.11 and $26.13 \mu \mathrm{g} \mathrm{TPF} \mathrm{g}^{-1}$ day $^{-1}$, respectively).

\section{Total phosphatase activity at 75 DAS}

The results obtained with respect to total phosphatase activity as influenced by different tillage practices and cropping systems (Table 2). Tillage practices had a significant influence on total phosphatase activity.

All the conservational tillage practices $\left(\mathrm{CT}_{1}\right.$, $\mathrm{CT}_{2}$ and $\mathrm{CT}_{4}$ ) except $\mathrm{CT}_{3}$ (no tillage with flatbed with crop residue retained on the surface, 166.99 $\mu \mathrm{g}$ PNP $\mathrm{g}^{-1} \mathrm{hr}^{-1}$ ) recorded significantly higher total phosphatase activity (172.44, 174.29 and 171.31 $\mu \mathrm{g}$ PNP g $\mathrm{gr}^{-1}$, respectively) as compared to conventional tillage with $\left(\mathrm{CT}_{5}, 160.77 \mu \mathrm{g}\right.$ PNP g$\left.{ }^{-1} \mathrm{hr}^{-1}\right)$ and without crop residue $\left(\mathrm{CT}_{6}, 149.79 \mu \mathrm{g}\right.$ PNP g ${ }^{-1}$ $\mathrm{hr}^{-1}$ ).
Among different cropping systems, cotton + groundnut $\left(\mathrm{CS}_{1}\right)$ recorded significantly higher total phosphatase activity (174.36 $\mu \mathrm{g} \mathrm{PNP} \mathrm{g}^{-1}$ $\mathrm{hr}^{-1}$ ) over sole cotton $\left(\mathrm{CS}_{4}, 158.23 \mu \mathrm{g}\right.$ PNP g ${ }^{-1}$ $\mathrm{hr}^{-1}$ ) and it was on par with pigeonpea + soybean $\left(\mathrm{CS}_{3}\right)$, sole pigeonpea $\left(\mathrm{CS}_{2}\right)$ and cotton + soybean $\left(\mathrm{CS}_{2}\right)(167.63,165.90$ and $163.54 \mu \mathrm{g}$ PNP $\mathrm{g}^{-1} \mathrm{hr}^{-1}$, respectively). With respect to the interaction effects, reduced tillage with $\mathrm{BBF}$ and incorporation of crop residue with intercropping of cotton + groundnut recorded significantly higher total phosphorus activity (184.97 $\mu \mathrm{g}$ PNP g ${ }^{-1}$ day $^{-1}$ ) over rest of the treatment combinations. Similarly, conventional tillage without crop residue with sole cotton recoded significantly lower total phosphatase activity $(140.63 \mu \mathrm{g}$ PNP $\mathrm{g}^{-1} \mathrm{hr}^{-1}$ ).

The greater stratification of enzyme activities under conservation agricultural practices might be due to vertical distribution of organic residues and microbial activity (Green et al., 2007).

And also less soil disturbance, crop residue incorporation or retention on the surface, root exudates from plants, availability of soil moisture, better soil aeration, decreased soil temperature and higher food reservoirs encouraged higher microbial population resulted in higher soil urease, dehydrogenase and phosphatase activity. Similar results were earlier reported by Castro Filho et al., (1991) and Nurbekov (2008). Where, minimum disturbance of soil combined with crop residue retention on the soil surface helped to get favourable environment which induced higher microbial activity resulted in greater soil enzymatic activity.

In present study it was observed that, conservation tillage systems either with $\mathrm{BBF} /$ flat bed and crop residues retention on the surface and incorporation treatments with intensive cropping systems of pigeonpea + 
soybean, cotton + groundnut and cotton + soybean led to significant improvement in soil biological health i.e. SMB-C, SMB-N and soil enzymatic activity over conventional tillage systems.

\section{Acknowledgment}

The authors acknowledge the Professor of Agronomy and Principle Investigator (PI), Project on Conservation Agriculture for Sustainable Production under rainfed situations for providing the necessary facilities for conducting the experiment.

\section{References}

Allen, D.E., B. P. Singh and R. C. Dalal. 2011. Soil health indicators under climate change: a review of current knowledge. In: Singh, B.P., Cowie, A.L., Chan, K.Y. (Eds.), Soil Health and Climate Change. SpringerVerlag, Berlin, Heidelberg, pp. 25-45.

Alvear, M., A. Rosas, J. L. Rouanetand F. Borie. 2005. Effect of three soil tillage systems on some biological activities in an Ultisol from southern Chile. Soil and Tillage Research. 82:195-202.

Balota, E.L., A. Colozzi-Filho, D. S. Andrade and R. P. Dick. 2003. Microbial biomass in soils under different tillage and crop rotation systems. Biology and Fertility of Soils. 38: 15-20.

Beare, M.H., P.F. Hendrix and D. C. Coleman. 1994. Water-stable aggregates and organic matter fractions in conventional and notillage soils. Soil Science Society of America Journal. 58, 777-786.

Campbell, C.A., H. H. Janzen and N. G. Juma. 2007. Case studies of soil quality in the Canadian prairies: long-term field experiments. In Soil Quality for Crop Production and Ecosystems Health, ed. E. G. Gregorich and M.R. Carter, 351-397. Amsterdam, The Netherlands: Elsevier.

Carter, M.R. 1999. Influence of Reduced Tillage Systems on Organic-Matter, Microbial Biomass, Macro-Aggregate Distribution and Structural Stability of the Surface Soil in A Humid Climate. Soil and Tillage Research. 23:361-372.

Carter, M.R.: Ninhydrin-reactive $\mathrm{N}$ released by the fumigation extraction method as a measure of microbial biomass under field conditions. Soil Biology and Biochemistry. 23:139-143.

Casida, L. E., D. A. Klen and J. Santoro. 1964. Soil dehydrogenase activity. Soil Science. 98:371-376.

Castro Filho, C., J. C. Henklain, M. J. Vieira and R. Casão. 1991. Tillage methods and soil and water conservation in southern Brazil. Soil and Tillage Research. 20: 271-283.

Christensen, N.B., W. C. Lindemann, E. Salazarsosaand L. R. Gill. 1994. Nitrogen and Carbon Dynamics in No-Till and Stubble Mulch Tillage Systems. Agronomy Journal. 86: 298-303.

Congreves, K.A., A. Hayes, L. L., Verhallen and L. L., Van Eerd. 2015. Long term impact of tillage and crop rotation on soil health at four temperate agroecosystems. Soil and Tillage Research. 152, 17-28.

Dick, R.P. 1992. A review: long-term effects of agricultural systems on soil biochemical and microbial parameters. Agriculture. Ecosystems Environmental.40: 25-36.

Doran, J.W., R. M. Zeiss. 2000. Soil health and sustainability: managing the biotic component of soil quality. Applied Soil Ecology. 15, 3-11.

Eivazi, Z. and M. A. Tabatabai. 1979. Phosphatase in soils. Soil Biology and Biochemistry. 9: 167-172.

Franzluebbers, A.J., R. L. Haney, F. M. Hons and D. A. Zuberer. 1999. Assessing biological soil quality with chloroform fumigationincubation: Why subtract a control? Canadian Journal of Soil Science. 79:521528.

Green, V.S., D. E. Stott, J.C. Cruz and N. Curi. 2007. Tillage impacts on soil biological activity and aggregation in a Brazilian Cerrado Oxisol. Soil and Tillage Research. 92:114-121.

Halvorson, A.D., J. W. Brian and L. B. Alfred. 2002. Tillage, nitrogen, and cropping system effects on soil carbon sequestration. Soil Science Society of America Journal. 66, 906-912. 
Insam, H. 2001. Developments in soil microbiology since the mid-1960s. Geoderma, 100: 389-402.

Karlen, D.L., C. A. Cambardella, J. L. Kovar and Colvin, T.S.: Soil quality response to longterm tillage and crop rotation practices. Soil and Tillage Research. 133: 54-64.

Montgomery, D.R. 2007. Soil erosion and agricultural sustainability. Proceedings of the National Academy of Sciences. 104:13268-13272.

Nurbekov, A. 2008. Microbial community responses to tillage and residue management on different soil types in southern Finland. Soil and Tillage Research. 23: 221-239.

Osunbitan, J.A., D. J. Oyedele and K. O., Adekalu. 2005. Tillage effects on bulk density, hydraulic conductivity and strength of a loamy sand soil in south-western Nigeria. Soil and Tillage Research. 82: 5764.

Ozpinar, S. and A. Cay. 2006. Effect of different tillage systems on the quality and crop productivity of a clay-loam soil in semi-arid North-Western Turkey. Soil and Tillage Research. 88:95-106.

Pancholy, S. K. and E. L. Rice. 1973. Soil enzymes in relation to old field succession: Amylase, invertase, cellulose, dehydrogenase and urease. Soil Science Society of America Journal. 37:47-50.

Powlson, D.S. and D. S. Jenkinson. 2005. A Comparison of the Organic-Matter,
Biomass, Adenosine-Triphosphate and Mineralizable Nitrogen Contents of Ploughed and Direct-Drilled Soils. Journal of Agricultural Sciences. 97:713-721.

Sasal, M. C., A. E. Andriulo and M. A. Taboada. 2006. Soil porosity characteristics and water movement under zero tillage in silty soils in Argentinian Pampas. Soil and Tillage Research. 87:9-18.

Spedding, T. A., C. Hamel, G. R. Mehuys and Madramootoo, C. A. 2004. Soil microbial dynamics in maize-growing soil under different tillage and residue management systems. Soil Biology and Biochemistry. 36 (2): 499-512.

Srinivasarao, C., B. Venkateswarlu, R. Lal, A. K. Singh and S. Kundu. 2013. Sustainable management of soils of dryland ecosystems of India for enhancing agronomic productivity and sequestering carbon. Advances in Agronomy. 121: 253-325.

Tabatabai, M.A. 2004. Soil enzymes. In Methods of soil analysis: Microbiological and biochemicalproperties, ed. R. W. Weaver, J.S. Angle, P. Bottomley, D. Bezdicek, S. Smith, A. Tabatabai, and A.G. Wollum, 775-827. Madison, WI: Soil Science Society of America.

Weller, D.M., J. M. Raaijmakers, B. B. M. Gardenerand L. S. Thomashow. 202. Microbial populations responsible for specific soil suppressiveness to plant pathogens. Annual Review of Phytopathology. 40:309-348.

\section{How to cite this article:}

Naveen Kumar, B.T. and Babalad, H.B. 2018. Influence of Conservation Agriculture Practices on Biological Soil Quality. Int.J.Curr.Microbiol.App.Sci. 7(03): 312-322.

doi: https://doi.org/10.20546/ijcmas.2018.703.037 